\title{
Keabsahan Identitas dalam Administrasi Kependudukan
}

\author{
Afdhal, S.H., M.Kn \\ Universitas Borneo Tarakan \\ Afdhalmr1@gmail.com
}

\begin{abstract}
This study aims to identify and explain the purpose of sticking client fingerprint To identify and explain the legal status of fingerprints on Electronic citizen Card (EKTP) with sticking client fingerprint on the public administration.

The research was conducted as an Empirical legal research with socio-legal research approach. The data were collected using structured interview techniques. Data were analyzed qualitatively.

The results of the study explained that the purpose of sticking clien fingerprint has not completely realized the legal assurance the correct fingerprint, consequently administration can not use the fingerprint data effectively. Fingerprints used by notaries and fingerprints appear on electronic citizen card have a legal status as authentic evidence of the a citizen's identity. Implementation sticking fingerprints do Civil Registry Office has a mechanism and standard operating procedure from the stage of registration, data entry and verification of data so that the results can be used as the information and valid. But sticking obligation fingerprint notaries do is rely on the interpretation of each requires a considerable time in the match the data client
\end{abstract}

\section{Purpose, Fingerprints, Public Administration}

\section{Pendahuluan}

Manusia sebagai zoon politicon merupakan mahluk yang bergantung kepada mahluk hidup lain untuk memenuhi kebutuhannya. Interaksi yang dilakukan antara sesama manusia dapat diwujudkan dalam berbagai bentuk. Hubungan yang terjadi antara manusia dengan manusia lainnya ini diatur oleh aturan yang dimaknai sebagai hukum. Hukum yang mengatur secara privat ini disebut sebagai hukum privat. Pada dasarnya hukum memiliki jangkauan aturan yang lebih luas tidak hanya kepada sesama manusia tetapi juga mengatur pemanfaatan sumber daya alam, mekanisme kelembagaan negara, perdagangan antara negara, kekuasaan dan profesi keahlian. 
Indonesia sebagai negara hukum yang memiliki kepadatan penduduk yang sangat besar. Jumlah penduduk di Indonesia juga menghasilkan masalah yang sangat rumit oleh karena itu pemerintah berkewajiban utnuk mengatur setiap unsur yang ada dalam masyarakat di dalam hukum yang bertujuan untuk menciptakan ketertiban umum dan kesejahteraan sosial.

Pemerintah mempunyai tugas untuk mendata masyarakat agar dapat mengetahui identitas dan mengatur setiap hal yang berhubungan dengan perbuatan hukum masyarakat tersebut. Kartu Tanda Penduduk merupakan kartu yang memuat tentang informasi penduduk sebagaimana dijelaskan oleh Undang-Undang Nomor 23 Tahun 2006 yang selanjutnya diubah oleh Undang-Undang Nomor 24 Tahun 2013 tentang Administrasi Kependudukan, utamanya setelah penyelenggaraan administrasi kependudukan bergulir sampai tahun 2012, maka pada tahun 2013 mulai dibuka akses data penduduk kepada instansi Pemerintah dan Lembaga Negara sesuai dengan aturan perundang-undangan. Data penduduk digunakan untuk berbagai kepentingan pembangunan dengan memerhatikan aspek kerahasiaan data yang bersifat privasi, dalam mengakses data dilakukan dengan sangat hati-hati dan dilandasi dengan Undang-Undang, Nota Kesepahaman (MOU) dan Perjanjian Kerja Sama (PKS).

Data kependudukan ini sangat berguna bagi setiap instansi agar dapat mengidentifikasi data kependudukan seseorang secara tepat. Sidik jari memiliki peran autentifikasi dan penjamin keabsahan identitas pada Elektronik Kartu Tanda Penduduk. Sidik Jari pada Elektronik Kartu Tanda Penduduk direkam dalam bentuk data pada sebuah chip seluler yang di tanamkan/dilaminating bersama dengan Elektronik Kartu Tanda Penduduk. 
Keabsahan identitas para pihak dalam perjanjian sangat berhubungan dengan informasi yang dapat di verifikasi melalui Elektronik KTP karena dalam E-KTP tersebut terdapat keterangan mengenai nama, tanggal lahir, alamat, foto, dan yang paling penting adalah sidik jari. Hal ini merupakan suatu kelebihan E-KTP yang dapat dimanfaatkan oleh para pihak ketika ingin membuat suatu perjajian.

Keabsahan hukum dapat diwujudkan apabila verifikasi terhadap identitas dapat dilakukan dengan teliti dan memiliki kecocokan dengan para pihak/penghadap. Beberapa masalah yang sering terjadi terkait kelalaian identitas adalah para pihak yang berhadapan bukan merupakan orang yang berhak tetapi menggunakan identitas yang di palsukan contohnya mengaku pasangan kawin ternyata bukan istri/suami yang sah, memilki wajah yang sama karena kembar atau bukan merupakan keturunan pertama dalam hibah, Masalah ini merupkan masalah hukum yang terjadi karena kesalahan mengidentifikasi identitas penghadap.

Instansi pelaksanaan Undang-Undang Nomor 24 Tahun 2013 tentang Aministrasi Kependudukan pada Pasal 27 ayat (1) adalah Dinas Kependudukan dan Pencatatan Sipil sebagai penyelenggara urusan Administrasi Kependudukan di Kabupaten/Kota dari ketentuan dimaksud mengamanatkan bahwa Kartu Keluarga (selanjutnya disingkat KK) dan Kartu Tanda Penduduk (selanjutnya disingkat KTP) merupakan dokumen resmi kependudukan yang diterbitkan dan ditandatangani oleh Instansi Pelaksana yang mempunyai kekuatan hukum sebagai alat bukti autentik yang dihasilkan dari pelayanan pendaftaran penduduk.

Ketentuan sebagaimana yang dimaksud d iatas memiliki aturan yang menjelaskan berupa Surat Edaran Kementerian Dalam Negeri Nomor 471.13/1826/S3 yang menerangkan bahwa Kartu Tanda Penduduk tidak berlaku lagi semenjak tanggal 01 Januari 2014 dan digantikan oleh 
Elektronik Kartu Tanda Penduduk yang penerapannya tidak diperkenankan untuk difoto copy.

Sidik jari (fingerprint) adalah hasil reproduksi tapak jari baik yang sengaja diambil, dicapkan dengan tinta, maupun bekas yang ditinggalkan pada benda karena pernah tersentuh kulit telapak tangan atau kaki. Sidik jari manusia digunakan untuk keperluan identifikasi karena tidak ada dua manusia yang memiliki sidik jari persis sama. Identifikasi sidik jari (daktiloskopi) sering digunakan di kalangan kepolisian.

Anatomi manusia, jempol atau ibu jari merupakan salah satu jari pada tangan yang dijadikan acuan pengambilan contoh sidik jari. Di Indonesia khususnya dalam bidang notariat sidik jari dipakai sebagai pengganti tanda tangan seseorang yang tidak dapat membubuhkan tanda tangannya, baik karena buta huruf maupun karena tangannya cacat atau lumpuh, suatu hal yang sering terjadi di Indonesia.

Berdasarkan latar belakang informasi yang memiliki keakuratan dan tingkat ketelitian yang tinggi maka penulis membahas dan menulis jurnal dengan Judul "KEABSAHAN IDENTITAS DIRI DALAM ADMINISTRASI KEPENDUDUKAN"

\section{Masalah dan Tujuan Penelitian}

a. Masalah dalam Penelitian ini adalah bagaimana keabsahan identitas dalam Administrasi Kependudukan

\section{Tinjauan Pustaka}

Ide negara hukum sesungguhnya telah lama dikembangkan oleh para filsuf dari zaman Yunani Kuno, Plato dalam bukunya "the Statesman" dan "the law" menyatakan bahwa negara hukum merupakan bentuk paling baik kedua (the second best) guna mencegah kemerosotan kekuasaan. Senada dengan Plato, tujuan negara menurut Aristotoles adalah untuk mencapai kehidupan yang 
paling baik (the best life possible) yang dapat dicapai dengan supremasi hukum. Hukum merupakan wujud kebijaksanaan kolektif warga negara (colletive wisdom), sehingga peran warga negara diperlukan dalam pemebentukanya.

Konsep negara hukum modern di Eropa Kontinental dikembangkan dengan menggunakan istilah Jerman yaitu "rechsstaat" antara lain oleh Imanuel Kant, Paul Laband, Julius Stahl, Fichte, dan lain- lain. Sedangkan dalam tradisi Anglo Saxon konsep negara hukum dikembangkan dengan sebutan "The Rule of Law" yang dipelopori oleh A.V.Dicey. Selain itu, konsep negara hukum juga terkait dengan istilah nomokrasi (nomocratie) yan berarti bahwa penentu dalam penyelenggaraan kekuasaan negara adalah hukum. ${ }^{1}$.

Prinsip-prinsip negara hukum selalu berkembang seiring dengan perkembangan masyarajat dan negara. Professor Utrecht membedakan dua macam negara hukum, yaitu negara hukum formal atau negara hukum klasik, dan negara hukum material atau negara hukum modern. negara hukum formal menyangkut pengertian hukum yang bersifat formal dan sempit, yaitu dalam arti peraturan perundang-undangan tertulis terutama. Tugas negara adalah melaksanakan peraturan perundang-undangan tersebut untuk menegakan ketertiban. ${ }^{2}$

\footnotetext{
${ }^{1}$ Jimly Asshiddiqie, Konstitusi dan Konstitusionalisme Indonesia, cetakan pertama, (Jakarta: Mahkamah Konstitusi Republik Indonesia Dan Pusat Studi Hukum Tata Negara Fakultas Hukum Universitas Indonesia,2004),hlm.122

${ }^{2}$ Utrecht, Pengantar Hukum Administrasi Negara Indonesia, (Jakarta: Ichtiar, 1962,hlm.9
} 
Tipe negara tradisional ini dikenal dengan istilah negara penjaga malam. Negera hukum material mencakup pengertian yang lebih luas termasuk keadilan didalamnya. Tugas negara tidak hanya menjaga ketertiban dengan melaksanakan hukum tetapi juga mencapai kesejahteraan rakyat sebagai bentuk keadilan (welfarestate). ${ }^{3}$

Berdasarkan berbagai prinsip negara hukum yang telah dikemukakan tersebut dan melihat kecenderungan perkembangan negara hukum modern yang melahirkan prinsip-prinsip penting baru untuk mewujudakan negara hukum, maka terdapat dua belas prinsip pokok sebagai pilar-pilar utama yang menyangga berdirinya negara hukum, kedua belas prinsip tersebut adalah: ${ }^{4}$

1. Supremasi Hukum(Supremacy of Law)

2. Persamaan dalam hukum(Equality Before The Law)

3. Asas Legalitas (Due Process of Law)

4. Pembatasan Kekuasaan

5. Organ-Organ Penunjang yang Independen

6. Peradilan Bebas dan Tidak Memihak

7. Peradilan Tata Usaha Negara

8. Mahkamah Konstitusi(Constitutional Court)

9. Perlindungan Hak Asasi Manusia

Secara normatif, prinsip bahwa setiap tindakan pemerintah harus berdasarkan peraturan perundang-undangan atau berdasarkan kewenangan memang dianut di setiap negara hukum, namun pada praktinya penerapan prinsip ini berbeda-beda. Ada negara yang begitu

${ }^{3}$ Ibid, Utrecht, Hal. 10

${ }^{4}$ Op cit, Jimly Asshiddiqie, Hal. 124

6|P a g e 
ketat berpegang pada prinsip ini, namun ada pula negara yang tidak begitu ketat menerapkannya ${ }^{5}$.

Menurut Bagir Manan, wewenang dalam Bahasa hukum tidak sama dengan kekuasaan (macht). Kekuasaan hanya menggambarkan hak untuk berbuat atau tidak berbuat, dalam hukum wewenang sekaligus berarti hak dan kewajiban (rechten en plichten). Dalam kaitan dengan otonomi daerah, hak mengandung pengertian kekuasaan untuk mengatur sendiri (zelfregelen) dan mengelola sendiri (zelfbesturen), sedangkan kewajiban secara horizontal berarti kekuasaan untuk menyelenggarakan pemerintahan sebagaimana mestinya. Vertikal berarti kekuasaan untuk menjalankan pemerintahan dalam suatu tertib ikatan pemerintahan negara secara keseluruhan. 6

Kewenangan administrasi kependudukan dilakukan oleh pemerintah untuk mendaftar peristiwa kependudukan dan peristiwa penting lainnya sebagaimana diatur Undang -Undang Nomor 24 Tahun 2013 Pasal 8 Ayat (1) Huruf a,:

(1) instansi Pelaksana melaksanakan urusan Administrasi Kependudukan dengan kewenangan yang meliputi:

a. memeroleh keterangan dan data yang benar tentang Peristiwa Kependudukan dan Peristiwa Penting yang dilaporkan Penduduk;

Instansi pelaksana data kependudukan untuk mencatat peristiwa penting menyangkut perbuatan hukum warga negara sebagaimana dimaksud Pasal 8 Ayat (1) di atas dilakukan oleh pemerintah kabupaten/kota yang bertanggung jawab menyelenggarakan urusan administrasi kependudukan yang kewenanganya meliputi:

a. Koordinasi penyelenggaraan Administrasi Kependudukan;

\footnotetext{
${ }^{5}$ Ridwan HR, Hukum Administrasi Negara Edisi Revisi, PT. Raja Grafindo Persada, Jakarta, Hal. 93

${ }^{6}$ Bagir Manan, wewenang provinsi kabupaten dan kota dalam rangka otonomi daerah, makalah pada seminar nasional, Fakultas Hukum UNPAD, Bandung, 13 Mei, Hlm. 1-2
} 
b. pembentukan Instansi Pelaksana yang tugas dan fungsinya di bidang Administrasi Kependudukan;

c. pengaturan teknis penyelenggaraan Administrasi Kependudukan sesuai dengan ketentuan Peraturan Perundang-undangan;

d. pembinaan dan sosialisasi penyelenggaraan Administrasi Kependudukan;

e. pelaksanaan kegiatan pelayanan masyarakat di bidang Administrasi Kependudukan;

f. penugasan kepada desa untuk menyelenggarakan sebagian urusan Administrasi Kependudukan berdasarkan asas tugas pembantuan;

g. pengelolaan dan penyajian Data Kependudukan berskala kabupaten/kota; dan

h. koordinasi pengawasan atas penyelenggaraan Administrasi Kependudukan ${ }^{7}$

1. Pengertian Sidik Jari

Sidik jari (bahasa Inggris: fingerprint) adalah hasil reproduksi tapak jari baik yang sengaja diambil, dicapkan dengan tinta, maupun bekas yang ditinggalkan pada benda karena pernah tersentuh kulit telapak tangan atau kaki. Kulit telapak adalah kulit pada bagian telapak tangan mulai dari pangkal pergelangan sampai kesemua ujung jari, dan kulit bagian dari telapak kaki mulai dari tumit sampai ke ujung jari yang mana pada daerah tersebut terdapat garis halus menonjol yang keluar satu sama lain yang dipisahkan oleh celah atau alur yang membentuk struktur tertentu. Fungsinya adalah untuk memberi gaya gesek lebih besar agar jari dapat memegang bendabenda lebih erat. Sidik jari manusia digunakan untuk keperluan identifikasi karena tidak ada dua manusia yang memiliki sidik jari persis sama

\footnotetext{
${ }^{7}$ Pasal 9 Ayat 1 Huruf a-d, Undang -Undang Nomor 23 Tahun 2006 Tentang Administrasi Kependudukan
} 
Sidik jari kaki bayi juga diambil di rumah sakit untuk identifikasi bayi. Ini bertujuan untuk mencegah tertukarnya bayi yang sering terjadi di rumah sakit. Fungsi sidik jari lainnya untuk menjadi bahan acuan penggunaan sidik jari, khususnya kepada para pihak yang tidak bisa membaca dan menulis sehingga mereka membubuhkan sidik jari/capjempol/ibu jari sebagai pengganti tanda tangannya; (bukannya 10 jari tangan dan kaki). Selain itu, suatu keadaan sakit (lumpuh) juga dapat mempengaruhi seseorang untuk mengganti tanda tangan dengan sidik jari/capjempol/ibu jari. Chip eKTP merupakan kartu pintar berbasis mikroprosessor dengan besaran memory 8 kilobytes. dengan antar muka nirkontak (contactless) dan memiliki metoda pengamanan data berupa autentikasi antara chip dan reader/writer (anti cloning), dan kerahasiaan data (enkripsi) serta tanda tangan digital.

Antar muka chip e-KTP memenuhi standar ISO 14443 A atau ISO 14443 B. Chip menyimpan biodata, tanda tangan, pas photo, dan 2 data sidik jari dengan kualitas terbaik saat dilakukan perekaman. Default-nya sidik telunjuk tangan kanan dan sidik jari telunjuk tangan kiri. Chip dapat dibaca oleh perangkat pembaca kartu (card reader) dengan standar antar muka ISO 14443 A dan ISO 14443 B.

Pemanfaatan kartu pintar (smart card) untuk e-KTP dengan chip yang memuat informasi data biodata, foto, citra tanda tangan dan 2 sidik jari telunjuk kanan dan kiri dan metode pengamanan yang tinggi, juga didukung oleh pemanfaatan teknologi biometric. Teknologi biometrics mampu untuk mengidentifikasi ketunggalan identitas penduduk dari hasil perekaman data penduduk wajib eKTP, sehingga dapat menghasilkan ketunggalan identitas penduduk (NIK yang unik dan tunggal) sebagai basis pembuatan database kependudukan nasional yang akurat dan data ketunggalan identitas 
pada e-KTP.Pemakaian teknologi biometrics dalam program e-KTP dapat dibagi ke dalam dua bagian:

1) Proses deduplikasi, uji ketunggalan identitas penduduk

2) Proses verifikasi pemilik e-KTP

Proses deduplikasi, uji ketunggalan identitas penduduk adalah pemadanan 1 terhadap N (1:N matching), dengan $\mathrm{N}$ adalah banyaknya record hasil perekaman data eKTP penduduk yang tersimpan di database e-KTP Data Center.

Proses identifikasi ketunggalan identitas dilakukan dengan memadankan (matching) data biometrics penduduk hasil perekaman di kecamatan/kelurahan, berupa 10 sidik jari, 2 iris mata dan foto wajah, yang dikirimkan ke Data Center, terhadap data biometrik penduduk lainnya yang telah tersimpan di database di Data Center eKTP Kemendagri.

Pemadanan ini hanya dilakukan berdasarkan informasi biometrics, tidak mengikutsertakan nama, tanggal lahir dan data lain. Dengan demikian upaya untuk membuat KTP ganda dengan mengubah nama, tanggal lahir dan sebagainya, tidak akan berhasil karena yang dipadankan adalah data biometrics penduduk. Data biometrics yang dipakai dalam proses deduplikasi adalah multimodal, yaitu fusi dari tiga jenis biometrics modality: 10 sidik jari, 2 iris dan wajah yang diintegrasikan lewat mekanisme tertentu. Apabila uji ketunggalan ini lolos, maka data tersebut akan masuk ke biro personalisasi yang akan mempersonalisasi kartu e-KTP dengan data penduduk baik personalisasi permukaan kartu e-KTP maupun personalisasi chip e-KTP. 
Dalam proses personalisasi tersebut, sidik jari telunjuk kanan dan sidik jari telunjuk kiri disimpan ke dalam chip e-KTP. Apabila kualitas perekaman sidik jari telunjuk kanan dan telunjuk kiri kurang baik untuk verifikasi sidik jari, maka sidik jari lain, yang memiliki kualitas lebih baik, yang akan disimpan di chip e-KTP untuk verifikasi sidik jari pemegang e-KTP. Informasi sidik jari mana yang direkam ini juga ikut disimpan di dalam chip.

Proses verifikasi dilakukan untuk memastikan apakah e-KTP tersebut dipegang oleh pemiliknya. Hal ini dilakukan lewat KTP reader, dimana warga diminta untuk meletakkan jari pada scanner, dan dilakukan 1:1 matching terhadap data sidik jari yang terekam di dalam chip. Berbeda dengan proses nomer 1, maka proses verifikasi yang kedua ini hanya mengandalkan informasi fitur sidik jari saja. Fitur ini yang kemudian diimplementasikan dalam compact e-KTP Reader

\section{Pembahasan}

Radbruch, Pengertian hukum dapat dibedakan dalam tiga aspek yang ketiga- tiganya diperlukan untuk sampai pada pengertian hukum yang memadai. Aspek yang pertama ialah keadilan dalam arti sempit. Keadilan ini berarti kesamaan hak untuk semua orang di depan peradilan. Aspek yang kedua ialah tujuan keadilan atau finalitas. Aspek ini menentukan isi hukum, sebab isi hukum memang sesuai dengan tujuan yang hendak dicapai. Aspek yang ketiga ialah kepastian hukum atau legalitas. Aspek itu menjamin bahwa hukum dapat berfungsi sebagai peraturan".

Tugas hukum adalah untuk mencapai kepastian hukum (demi adanya ketertiban) dan keadilan di dalam masyarakat. Menurut Soerjono Soekanto "Kepastian hukum mengharuskan diciptakannya peraturan-peraturan umum atau kaedah-kaedah yang berlaku 
umum, supaya tercipta suasana yang aman dan tentram di dalam Masyarakat.

Kepastian hukum dapat dicapai apabila dalam situasi tertentu

a. Tersedia aturan-aturan hukum yang jelas (jernih), konsisten dan mudah diperoleh (accessible)

b. Instansi-instansi penguasa (pemerintah) menerapkan aturan-aturan hukum tersebut secara konsisten dan juga tunduk dan taat tersebut

c. Warga secara prinsipil menyesuaikan perilaku mereka terhadap aturan-aturan tersebut

d. Hakim-hakim (peradilan) yang mandiri dan tidak berpihak menerapakan aturan-aturan hukum tersebut secara konsisten sewaktu mereka menyelesaikan sengketa hukum

e. Keputusan peradilan secara kongkrit dilaksanakan.

Secara normatif, prinsip bahwa setiap tindakan pemerintah harus berdasarkan peraturan perundang-undangan atau berdasarkan kewenangan memang dianut di setiap negara hukum, namun pada praktinya penerapan prinsip ini berbeda-beda. Ada negara yang begitu ketat berpegang pada prinsip ini, namun ada pula negara yang tidak begitu ketat menerapkannya.

Menurut Bagir Manan, wewenang dalam Bahasa hukum tidak sama dengan kekuasaan (macht). Kekuasaan hanya menggambarkan hak untuk berbuat atau tidak berbuat, dalam hukum wewenang sekaligus berarti hak dan kewajiban (rechten en plichten). Dalam kaitan dengan otonomi daerah, hak mengandung pengertian kekuasaan untuk mengatur sendiri (zelfregelen) dan mengelola sendiri (zelfbesturen), sedangkan kewajiban secara horizontal berarti kekuasaan untuk menyelenggarakan pemerintahan sebagaimana mestinya. Vertikal berarti kekuasaan untuk 
menjalankan pemerintahan dalam suatu tertib ikatan pemerintahan negara secara keseluruhan.

Kewenangan administrasi kependudukan dilakukan oleh pemerintah untuk mendaftar peristiwa kependudukan dan peristiwa penting lainnya sebagaimana diatur Undang -Undang Nomor 24 Tahun 2013 Pasal 8 Ayat (1) Huruf a,:

(1) instansi Pelaksana melaksanakan urusan Administrasi Kependudukan dengan kewenangan yang meliputi:

(2) memeroleh keterangan dan data yang benar tentang Peristiwa Kependudukan dan Peristiwa Penting yang dilaporkan Penduduk;

Instansi pelaksana data kependudukan untuk mencatat peristiwa penting menyangkut perbuatan hukum warga negara sebagaimana dimaksud Pasal 8 Ayat (1) di atas dilakukan oleh pemerintah kabupaten/kota yang bertanggung jawab menyelenggarakan urusan administrasi kependudukan yang kewenanganya meliputi:

1. Koordinasi penyelenggaraan Administrasi Kependudukan;

2. pembentukan Instansi Pelaksana yang tugas dan fungsinya di bidang Administrasi Kependudukan;

3. pengaturan teknis penyelenggaraan Administrasi Kependudukan sesuai dengan ketentuan Peraturan Perundang-undangan;

4. pembinaan dan sosialisasi penyelenggaraan Administrasi Kependudukan;

5. pelaksanaan kegiatan pelayanan masyarakat di bidang Administrasi Kependudukan;

6. penugasan kepada desa untuk menyelenggarakan sebagian urusan Administrasi Kependudukan berdasarkan asas tugas pembantuan; 
7. pengelolaan dan penyajian Data Kependudukan berskala kabupaten/kota; dan

8. koordinasi pengawasan atas penyelenggaraan Administrasi Kependudukan

Secara teoritik, kewenangan yang bersumber dari peraturan perundang-undangan diperoleh melalui tiga cara yaitu atribusi, delegasi, dan mandate, Indroharto mengatakan bahwa pada atribusi terjadi pemberian wewenang pemerintah yang baru oleh suatu ketentuan dalam peraturan perundang-undangan. Pada delegasi terjadilah pelimpahan suatu wewenang yang telah ada oleh Badan atau Jabatan Tata Usaha Negara yang telah memeroleh wewenang pemerintah secara atributif kepada Badan atau Jabatan Tata usaha Negara lainnya, jadi suatu delegasi selalu didahului oleh adanya suatu atribusi wewenang.

Mengenai atribusi, delegasi dan mandate ini H.D. Van Wijk/ Willem Konijnenbelt mendefinisikan sebagai berikut:

a) Atribusi adalah pemberian wewenang pemerintah oleh pembuat undang-undang kepada organ pemerintahan.

b) Delegasi adalah pelimpahan wewenang pemerintah dari satu organ pemerintahan kepada organ pemerintahan lainnya.

c) Mandat terjadi ketika organ pemerintahan mengizinkan kewenangannya dijalankan oleh organ lain atas namanya.

Pembagian mengenai sifaf wewenang pemerintahan yakni terikat, fakultatif, dan bebas, dalam kaintannya dengan kewenangan pembuatan dan penerbitan keputusan-keputusan (beschikkingen) oleh organ pemerintahan, sehingga dikenal ada keputusan yang bersifat terikat, yakni terjadi apabila peraturan dasarnya menentukan kapan dan dalam keadaan yang bagaimana wewenang tersebut dapat digunakan atau peraturan dasarnya sedikit banyak 
menentukan tentang isi dari putusan yang harus diambil secara terinci, maka wewenang pemerintah semacam itu merupakan wewenang terikat

Wewenang Fakultatif, terjadi dalam hal badan atau pejabat tata usaha negara yang bersangkutan tidak wajib menerapkan wewenangnya atau sedikit banyak masih ada pilihan sekalipun pilihan itu hanya dapat dilakukan dalam hal-hal atau keadaan-keadaan tertentu sebagaimana ditentukan dalam peraturan dasarnya. ${ }^{8}$

Philipus M. Hadjon, dengan mengutip pendapat spelt dan Ten Berg, membagi kewenangan Bebas dalam dua kategori, yaitu Kebebasan kebijaksanaan (beleidsvrijheid) bila peraturan perundang-undangan memberikan wewenang tertentu kepada organ pemerintahan sedangkan organ tersebut tidak menggunakanya meskipun syaratsyarat bagi pelaksana suatu wewenang secara sah telah dipenuhi berdasarkan pengertian ini maka disimpulkan ada dua jenis kekuasaan bebas yaitu:

a. Kewenangan untuk memutuskan secara mandiri

b. Kewenangan terhadap interpretasi terhadap norma-norma tersamar (vage norm) Asas-Asas Umum Penyelenggaraan Negara ${ }^{9}$

Undang-Undang Nomor 28 Tahun 1999 tentang Penyelenggaraan Negara Yang Bersih Dan Bebas Dari Korupsi, Kolusi, Dan Nepotisme (selanjutnya disebut KKN) sebagaimana diatur dalam Pasal 3 menjelaskan beberapa asas umum penyelenggaraan negara, yaitu: ${ }^{10}$

a. Asas Kepastian Hukum, yaitu asas dalam negara hukum yang mengutamakan landasan peraturan perundang-undangan,

\footnotetext{
${ }^{8}$ dari Indroharto, op.cit., hlm 108

${ }^{9}$ Philipus M. Hadjon, Perlindungan HukumBagi Rakyat di Indonesia, Bina Ilmu, Surabaya, hlm. 171

${ }^{10}$ Indroharto, op.cit., Hlm. 241
} 
kepatutan dan keadilan dalam setiap kebijakan penyelenggaraan negara

b. Asas Tertib Penyelenggaraan Negara, yaitu asas yang menjadi keteraturan, keserasian, dan keseimbangan dalam pengendalian penyelenggaraan negara

c. Asas Kepentingan Umum, yaitu Asas yang mendahulukan kesejahteraan umum dengan cara aspiratif, akomodatif, dan selektif.

d. Asas Keterbukaan, yaitu asas yang membuka diri terhadap hak masyarakat untuk memeroleh informasi yang benar, jujur, dan tidak diskriminatif tentang penyelenggaraan negara dengan tetap memerhatikan perlindungan atas hak asasi pribadi, golongan, dan rahasia negara.

e. Asas proporsionalitas, yaitu asas yang mengutamakan keseimbangan antara hak dan kewajiban penyelenggaraan negara negara.

f. Asas Profesionalitas, yaitu asas yang mengutamakan keahlian yang berlandaskan kode etik dan ketentuan peraturan perundang-undangan yang berlaku.

g. Asas Akuntabilitas, yaitu asas yang menentukan setiap kegiatan dan hasil akhir dari kegiatan penyelenggaraan negara harus dapat dipertanggung jawabkan kepada masyarakat atau rakyat sebagai pemegang kedaulatan tertinggi negara sesuai dengan peraturan perundang-undanganyang berlaku. 
KESIMPULAN

Kedudukan Hukum sidik jari yang dilakukan oleh notaris dan Sidik jari yang terdapat pada KTP-el, yaitu sebagai bukti Autentik terhadap keterangan identitas penduduk. Pelaksanaan pelekatan sidik jari yang dilakukan Dinas Catatan Sipil memiliki mekanisme dan aturan yang jelas mulai dari tahap pendaftaran, pemasukan data dan verifikasi data sehingga hasilnya dapat digunakan sebagai informasi yang valid/sah

\section{DAFTAR PUSTAKA}

\section{Buku-Buku:}

Adjie, Habib. 2008. Hukum Notaris di Indonesia-Tafsiran Tematik Terhadap UU No. 30 Tahun 2004 Tentang Jabatan Notaris. Bandung. PT.Refika Aditama

Bryan, A. Garner (ed).Black's Law Dictionary, 2nd Pocket Edition. ST. Paul,Minn,:west Group

Buku Pedoman Ikatan Notariat.1996. Indonesia

Durachman, Yusuf. 2011. Aplikasi Pembuatan E-KTP (Kartu Tanda Penduduk) Menggunakan Kode Batang Berbasis Web (Studi Kasus: Kabupaten Tanjung Jabur Timur Provinsi Jambi). Jakarta. Fakultas Sains dan TeknologiUniversitas Islam Negeri Syarif Hidayatullah

Dwi, Saputra. Asbudi. 2012. Pertanggungjawaban Pidana Notaris/PPAT Selaku Pejabat Umum Dalam Pemalsuan Dokumen Akta Tanah. Program Kenotariatan. Makassar. Fakultas Hukum, Universitas Hasanuddin

Ghofur, Anshori. Abdul. 2013. Lembaga Kenotariatan Indonesia Perspektif Hukum dan Etika. Yogyakarta . UII Press

Harahap, Yahya. 2004 Pembahasan Permasalahan dan Penerapan KUHAP Pemeriksaan Sidang di Pengadilan,Banding,Kasasi dan Peninjauan Kembali. Jakarta. Sinar Grafika

Harsono, Budi. 2002. Hukum Agraria Indonesia. Jakarta. Djambatan.

Hujibers, Theo. 1982. Filsafat Hukum Dalam Lintasan Sejarah. Yogyakarta. Kanisius

Keputusan Sidang Konggres INI ke XV, tanggal 6 Nopember 1993 di Jakarta Kie, Thong Tan. 2000. Studi Notariat Serba Serbi Pratek Notaris. Jakarta.PT. Ichtiar Baru Van Hoeve 
Kohar A. 2006 Notaris dan Persoalan Hukum. Surabaya. PT. Bina Indra Karya.

Mertokusumo, Sudikno. 1998. Hukum Acara Perdata Indonesia. Yogyakarta. Liberty

Notodisoeryo, Sugondo R. Hukum Notariat di Indonesia: Suatu Penjelasan. PT Raja Grafindo Persada

Otto, Micheil Jan. 2003. Kepastian Hukum di Negara Berkembang, terjemahan Tristam Moeliono. Jakarta. KomisiHukum nasional

Parangin, Effendi. 1994. Hukum Agraria di Indonesia. Jakarta. Raja Grafindo Persada.

Parlindungan, A.P. 1989 Bunga Rampai Hukum Agraria Serta Landreform. Bandung. Bagian I

Soekanto, Soerjono. 1999 Beberapa Permasalahan Hukum Dalam Kerangka Pembangunan di Indonesia (suatu tinjauan secara sosiologis), cetakan keempat. Jakarta Universitas Indonesia

Soekanto, Seorjono dan Mamuji Sri. 1984. Penelitian Hukum Normatif, Jakarta. Rajawali

Soemitro, Hanitijo Ronny. 1990. Metodologi Penelitian Hukum dan Jurimetri, Jakarta, Ghalia Indonesia

Tobing, Lumban G.H.S. 1983 Peraturan Jabatan Notaris. Jakarta. Erlangga

\section{Undang-Undang dan Aturan Lainnya:}

- Undang-undang No. 4 tahun 1996 tentang Hak Tanggungan atas tanah beserta benda-benda yang berkaitan dengan tanah

- Undang-undang nomor 11 Tahun 2004 Tentang Informasi dan Transaksi Elektronik

- Undang-undang Jabatan Notaris Nomor 30 Tahun 2004

- Undang-Undang Nomor 43 Tahun 2009 Tentang Kearsipan

- $\quad$ Undang-Undang Administrasi Kependudukan Nomor 24 Tahun 2013

- Undang-Undang Nomor 2 Tahun 2014 Tentang Jabatan Notaris

- Peraturan Pemerintah No.24 tahun 1997 tentang pendaftaran tanah

- Peraturan Pemerintah No. 37 tahun 1998 Tentang Jabatan PPAT 
- Keputusan Menteri Agraria/ Kepala Badan Pertanahan Nasional Nomor 4 Tahun 1999 tentang Penetapan Formasi PPAT di Kabupaten/Kotamadya

- ordonansi stbl.1867-29 yang berjudul: Bepalingen nopens de bewjskrscht van onderhandse geschriftenvan indonesiers of met hen gelijkgestelde personen

\section{Pustaka Online}

Cahyono. Otentifikasi Informasi Dan Fisik Arsip, Direktorat Jenderal Administrasi Hukum Umum. PJS. KABAG TATA USAHA. power point. http://www.hukumonline.com/berita/baca/lt52f8ed03d67c9/aturankewajiban-sidik-jari-di-uu-bikin-bingung-notaris 